\title{
Modulation of Defense Responses of Malus spp. During Compatible and Incompatible Interactions with Erwinia amylovora
}

\author{
Jean-Stéphane Venisse, ${ }^{1}$ Mickaël Malnoy, ${ }^{1}$ Mohamed Faize, ${ }^{1}$ Jean-Pierre Paulin, ${ }^{2}$ and \\ Marie-Noëlle Brisset ${ }^{2}$ \\ ${ }^{1}$ Unité d'Amélioration des Espèces Fruitières et Ornementales, INRA; and ${ }^{2}$ UMR Pathologie Végétale INRA/INH/UA, \\ Centre INRA d'Angers, 42 rue Georges Morel, BP 57, 49071 Beaucouzé Cédex, France
}

Submitted 15 May 2002. Accepted 31 July 2002.

\begin{abstract}
Erwinia amylovora is the causal agent of fire blight, a disease affecting members of subfamily Maloideae. In order to analyze mechanisms leading to compatible or incompatible interactions, early plant molecular events were investigated in two genotypes of Malus with contrasting susceptibility to fire blight, after confrontation with either $E$. amylovora or the incompatible tobacco pathogen Pseudomonas syringae pv. tabaci. Many defense mechanisms, including generation of an oxidative burst and accumulation of pathogenesis-related proteins, were elicited in both resistant and susceptible genotypes by the two pathogens at similar rates and according to an equivalent time course. This elicitation was linked with the functional hypersensitive reaction and pathogenicity ( $h r p$ ) cluster of $E$. amylovora, because an $h r p$ secretion mutant did not induce such responses. However, a delayed induction of several genes of various branch pathways of the phenylpropanoid metabolism was recorded in tissues of the susceptible genotype challenged with the wild-type strain of E. amylovora, whereas these genes were quickly induced in every other plant-bacteria interaction, including interactions with the hrp secretion mutant. This suggests the existence of $h r p$-independent elicitors of defense in the fire blight pathogen as well as hrp-dependant mechanisms of suppression of these nonspecific inductions.
\end{abstract}

Additional keyword: apple.

Plant disease resistance against phytopathogenic organisms generally is associated with the induction of de novo defense mechanisms (Hammond-Kosack and Jones 1996; Hutcheson 1998). This induction presupposes recognition of the invading pathogen by receptors of the plant cell and the existence of signal-transduction pathways leading to the activation of plant defense genes. The first line of defense involves cells immediately confronted with the pathogen. These cells undergo many metabolic changes, such as reactive oxygen species (ROS) production, ion fluxes, and protein phosphorylations, frequently leading to their death. Such a phenomenon is currently called the hypersensitive response (HR). The second line of defense involves adjacent cells surrounding the infection site and is associated with localized acquired resistance (LAR). Cell wall reinforcement, as well as accumulation of antioxidant enzymes, pathogenesis-related (PR) proteins, and phy-

Corresponding author: M. N. Brisset; Telephone: +33 2412257 13; Fax: +332412257 05; E-mail:brisset@angers.inra.fr toalexins (through the stimulation of secondary metabolic pathways) typically are observed. PR proteins also can be synthesized throughout the plant and lead to systemic acquired resistance (SAR), which represents the third line of defense.

Disease occurs when the pathogen is not detected or, if detected, when it is able to escape or at least to cope with plant defense responses. Defense may be either not activated or activated too late with regard to tissue colonization by the pathogen. Several strategies (described essentially for fungi) have been deployed by pathogens, involving either suppressors of elicitation of plant defense molecules (Shiraishi et al. 1994) or inhibitors of induced defense molecules (Schäfer 1994). Concerning phytopathogenic bacteria, several species are known to possess hypersensitive reaction and pathogenicity ( $h r p$ ) genes which control their ability to cause disease and to elicit hypersensitive reactions on nonhost or resistant plants (Cornelis and van Gijsegem 2000). These genes encode components of a type III secretion system, involved in the secretion of pathogenicity proteins. Several studies on Xanthomonas campestris and Pseudomonas syringae suggest that some hrp genes could act to suppress particular defense responses during compatible interactions (Brown et al. 1995; Jakobek et al. 1993; Kamoun et al. 1992; Newman et al. 2001).

Fire blight is a disease of species belonging to subfamily Maloideae of the family Rosaceae, including apple (Malus spp.), pear (Pyrus spp.), and ornamentals such as Cotoneaster and Pyracantha spp., and is caused by the necrogenic bacteria Erwinia amylovora. Infection occurs via natural openings such as nectaries in flowers or via wounds on leaves or on succulent shoots. In susceptible cultivars, multiplication and progression of bacteria in parenchyma is followed by necrosis of progressively invaded tissues; whereas, in resistant cultivars, the necrosis is restricted to the infection site. Conversely, to a number of plant-pathogen interactions, no specific $R / A v r$ gene combinations have been described in the case of fire blight. This suggests that resistance against fire blight disease is under a polygenic determinism.

E. amylovora has been studied intensively at the molecular level. It has a type III Hrp secretory apparatus which secretes at least seven proteins (Kim and Beer 2000). Four of them have been described for their involvement in HR or disease reaction: HrpN (Barny 1995; Wei et al. 1992), DspA/E (Bogdanove et al. 1998; Gaudriault et al. 1997), HrpW (Gaudriault et al. 1998; Kim and Beer 1998), and HrpA (Jin et al. 2001). However, except for HrpA, which is a structural protein of the Hrp pilus, the biological function of the Hrp-secreted proteins remains to be clarified. In addition, exopoly- 
saccharides (EPS), whose synthesis is controlled by an amylovoran synthesis (ams) cluster, is another major pathogenicity determinant of E. amylovora which may protect the bacteria against host defense reactions (Bugert and Geider 1995). Finally the production of a bacterial hydroxamate-type siderophore (desferrioxamine) under iron-limiting conditions is an additional virulence determinant of the bacteria (Dellagi et al. 1998).

Recently we showed that E. amylovora is able to induce locally in susceptible host plants (pear seedlings) the production of ROS and its immediate consequences (lipid peroxidation and activation of antioxidant enzymes) with kinetics similar to those induced by an incompatible bacteria, Pseudomonas syringae pv. tabaci (Venisse et al. 2001). This ability clearly is related to Hrp-secreted proteins because an hrp-secretion mutant of E. amylovora was unable to induce any oxidative stress. These results suggest that the fire blight pathogen is detected as an incompatible pathogen by its host plants and uses the generation of active oxygen species to kill the plant cells. However they raised the question of how the pathogen is able to overcome the plant defenses usually triggered by such an oxidative burst and to colonize its susceptible hosts.

To address this question, we investigated a wide panel of defense-related mechanisms, including anti-oxidative enzymes, PR proteins, and key enzymes of the phenylpropanoid pathway, after infection of a susceptible and a resistant genotype of Malus by a virulent wild-type strain of E. amylovora. Plant responses were compared to those obtained from the same genotypes of Malus challenged with a nonvirulent hrp secretory mutant of E. amylovora and with the tobacco pathogen $P$. syringae pv. tabaci, both used as controls.

\section{RESULTS}

\section{Symptoms observed after various methods of inoculation.}

Complete analysis of defense-related mechanisms was performed in leaves of the susceptible genotype MM106 and the resistant genotype Evereste after leaf infiltration of strain $E$. amylovora CFBP1430 (wild type, WT), strain P. syringae pv. tabaci CFBP2106 (wild type, WT), and strain PMV6023 (hrp secretory mutant of E. amylovora WT, E. amylovora hrp). Some experiments were performed on flowers and shoots of the susceptible genotype challenged with E. amylovora WT with E. amylovora hrp used as control.

Leaf infiltration of each apple genotype with each of the wild-type strains, E. amylovora WT or $P$. syringae pv. tabaci $\mathrm{WT}$, at a concentration of $10^{7} \mathrm{CFU} / \mathrm{ml}$, led within $24 \mathrm{~h}$ to similar necrotic spots surrounded by apparently healthy tissues. In the E. amylovora WT-MM106 combination only, progressive necrosis could be observed on and after 6 days, reaching first the midrib and nearby tissues, then the petiole and the shoot. At higher inoculum concentrations, each wild-type strain provoked necrosis of the whole infiltrated area within $24 \mathrm{~h}$. Inocula at a concentration of $10^{7} \mathrm{CFU} / \mathrm{ml}$ were chosen for molecular studies of plant responses, allowing the analysis in the infiltrated areas of the second line of defense described above (mainly responses of apparently healthy tissues).

Blossom inoculation of the susceptible genotype MM106 with E. amylovora WT led to the appearance of a progressive necrosis on flowers and peduncles after 4 days, whereas no symptoms could be observed on flowers of the resistant genotype Evereste inoculated in the same conditions. Flowers and peduncles of MM106 showed complete necrosis 8 days after inoculation. Molecular studies were conducted on flowers and peduncles of MM106 during the course of necrosis development.

For shoot studies, wounding inoculation of leaves was performed. Inoculation of MM106 by E. amylovora WT led to a progressive necrosis along the midrib reaching the shoot within 10 days, whereas Evereste inoculated in the same conditions showed necrosis restricted to the inoculation site only. Molecular studies were conducted on apparently healthy parts of shoots of MM106 scions, just beyond the necrosis.

The mutant E. amylovora hrp did not produce any visible symptoms whatever the method of inoculation or plant genotype. Molecular studies were performed on parts of plants (leaves, flowers, or shoots) equivalent to those sampled from plants inoculated with E. amylovora WT.

\section{$\mathrm{O}_{2}{ }^{\circ-}$ production during the course of disease.}

Generation of superoxide anion $\mathrm{O}_{2}{ }^{\circ-}$ was qualitatively detected in flowers and stems of the susceptible cultivar MM106 after inoculation of $E$. amylovora WT, using reduction of nitroblue tetrazolium (NBT) as an indicator (accumulation of insoluble blue-colored formazan complex) (Doke 1983). Strong blue staining was found in each organ in apparently healthy areas just ahead of necrosis (Fig. 1). Control plants inoculated with E. amylovora hrp did not show any reaction.

\section{Defense enzymes activities.}

Activities of two antioxidative enzymes of the glutathioneascorbate cycle, ascorbate peroxidase (APOX; EC 1.11.1.11) and glutathione reductase (GR; EC 1.6.4.2), and three families of PR proteins, peroxidase (POX; EC 1.11.1.7), $\beta$-1,3-glucanase (GLU; EC 3.2.1.6), and chitinase (CHT; EC 3.2.1.14), were analyzed in leaves of both cultivars, Evereste and MM106, infiltrated by E. amylovora WT, P. syringae pv. tabaci WT, or E. amylovora hrp. The two wild-type strains, $E$. amylovora WT and $P$. syringae pv. tabaci WT, induced similar activation of each enzyme in the resistant as well as in the susceptible genotype (Fig. 2). All enzyme activities increased significantly from 18 to $24 \mathrm{~h}$ after bacterial infiltration. High levels of APOX and GLU activities were reached from $24 \mathrm{~h}$ after bacterial infiltration, whereas kinetics of GR, CHT, and POX

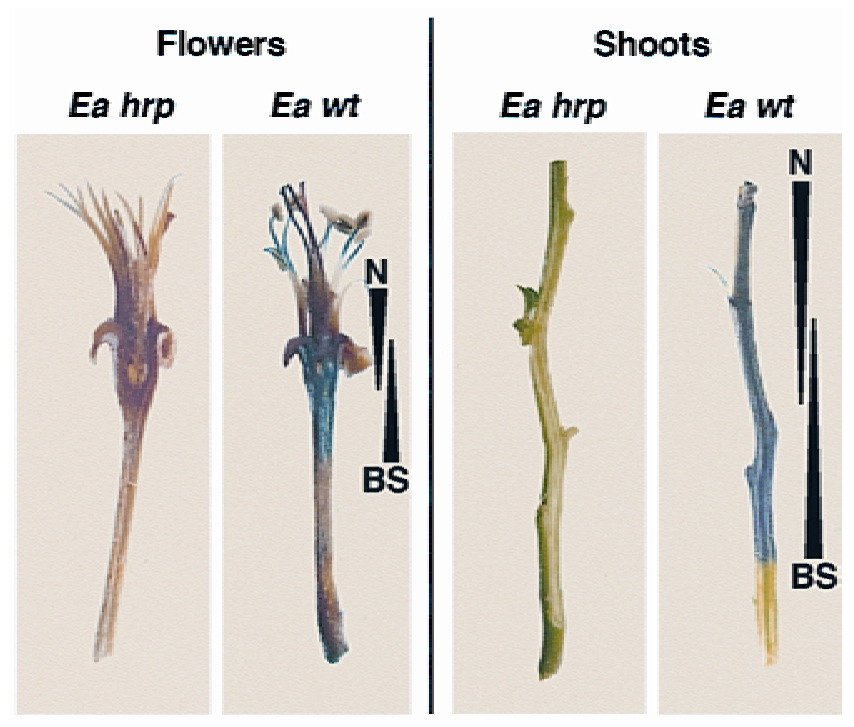

Fig. 1. Superoxide anion $\mathrm{O}_{2}{ }^{\mathrm{o}}$ generation bioassay in flowers and shoots of the susceptible genotype MM106. A, Flowers were sampled 4 days after deposit of a drop of bacterial suspensions $\left(10^{7} \mathrm{CFU} / \mathrm{ml}\right)$ into the hypanthium. B, Shoots were sampled 10 days after deposit of a drop of bacterial suspensions $\left(10^{7} \mathrm{CFU} / \mathrm{ml}\right)$ onto a fresh cut made on young developed leaves. Samples were vacuum infiltrated with a $0.5 \%$ solution of nitroblue tetrazolium and photographed $30 \mathrm{~min}$ later. Spreading of blue staining (BS), which indicates qualitatively the presence of $\mathrm{O}_{2}{ }^{\circ-}$, and of necrosis $(\mathrm{N})$ are indicated by triangles. Ea wt = wild-type strain of Erwinia amylovora CFBP1430; Ea hrp = hrp secretion mutant PMV6023 derived from CFBP1430. 
activities were slightly delayed with a maximum from $36 \mathrm{~h}$ for GR and $48 \mathrm{~h}$ for CHT and POX. The mutant E. amylovora hrp did not induce any significant activation of these enzymes compared with their constitutive levels of activity. On the whole, no obvious difference was recorded between the genotypes, except a higher constitutive level of GR activity in the resistant one (108 versus $68 \mathrm{nmol}$ NADPH per mg of protein per min).


Fig. 2. $\mathbf{A}$ and $\mathbf{B}$, Ascorbate peroxidase, $\mathbf{C}$ and $\mathbf{D}$, glutathione reductase, $\mathbf{E}$ and $\mathbf{F}$, chitinase, $\mathbf{G}$ and $\mathbf{H}, \beta-1,3$-glucanase, and $\mathbf{I}$ and $\mathbf{J}$, peroxidase activities in protein extracts from leaves of the susceptible genotype MM106 (A, C, E, G, and I) and the resistant genotype Evereste $(\mathbf{B}, \mathbf{D}, \mathbf{F}$, $\mathbf{H}$, and $\mathbf{J}$ ) infiltrated with bacterial suspensions of wild-type Erwinia amylovora CFBP1430 (Ea wt), its hrp secretion mutant PMV6023 (Ea $h r p$ ), and wild-type Pseudomonas syringae pv. tabaci CFBP2106 (Pst wt) at concentrations of $10^{7} \mathrm{CFU} / \mathrm{ml}$. Enzyme activities are expressed in $\mu$ mole of ascorbic acid per mg of proteins and per min (ascorbate peroxidase; APOX), in nmol of NADPH per mg of proteins and per minute (glutathione reductase; GR), in increase of absorbance at 550 and $600 \mathrm{~nm}$ per $\mathrm{mg}$ of proteins and per min (chitinase [CHT] and $\beta-1,3$-glucanase [GLU], respectively), in $\mu$ mole of tetraguaiacol per mg of proteins and per min (peroxidase; POX) $++=$ constitutive enzyme activities. Data are means $\pm \mathrm{SE}$ of at least six repetitions from three independent experiments.
Expression of defense genes.

Sequence analysis of cloned fragments of defense genes from Evereste and from MM106 which encode PR proteins (CHT, GLU, and PR-5) or enzymes of the phenylpropanoid pathway (L-phenylalanine ammonia-lyase [PAL], chalcone synthase [CHS], chalcone isomerase [CHI], flavonol synthase [FLS], and dihydroflavonol reductase [DFR]) indicated that the primers used in our experiments amplified distinct groups of transcripts of each defense gene except PAL. Defense genes are known to belong to multigenic families; therefore, these groups probably correspond to different isoforms. The nucleic acid sequences of these fragments have been submitted to GenBank at the National Center for Biological Information (NCBI, Bethesda, MD, U.S.A.) and the accession numbers are listed in Table 1.

Temporal expression of these gene families then was analyzed through semi-quantitative reverse transcription polymerase chain reaction (RT-PCR) in leaves of both cultivars infiltrated with $E$. amylovora WT, $P$. syringae pv. tabaci WT, $E$. amylovora hrp, or sterile distilled water. No significant transcript accumulation of defense genes was detected after infiltration of the water control in each genotype (Fig. 3 for MM106, not shown for Evereste). In tissues infiltrated with bacteria, two major patterns of expression of defense genes were observed (Fig. 3). Increasing transcript steady state levels were observed for the three PR proteins as well as for PAL and $\mathrm{CHI}$ in tissues of both genotypes infiltrated with E. amylovora WT and P. syringae pv. tabaci WT when compared with those infiltrated with the mutant E. amylovora hrp or the water control. These increases were either transient (CHT, PAL, and $\mathrm{CHI}$ ) or stable for the whole duration of the experiment (up to $72 \mathrm{~h}$ post infiltration) (GLU, PR-5). No striking difference could be detected in kinetics and amplitude of expression of these genes between the various genotype-wild-type strain combinations tested. It is of special interest, for the value of the RT-PCR as a semi-quantitative technique, to highlight the strong correlation found between the transcript levels and the enzyme activities for both CHT and GLU, with an interval of approximately $24 \mathrm{~h}$ between their kinetics of accumulation (Figs. 2 and 3).

The second pattern of expression of defense genes was observed for CHS, DFR, and FLS. Transcript steady state levels of these three enzymes increased in every plant-bacteria situation (including those involving $E$. amylovora $h r p$ ), except in the compatible one (i.e., MM106-E. amylovora WT). In this last case, the wild-type strain of E. amylovora seemed to prevent, at least transiently, the induction of the corresponding genes (Fig. 3). This ability was further investigated in shoots and flowers of MM106 undergoing a progressive invasion of the bacteria. Plant responses were compared with responses of control plants inoculated with E. amylovora hrp. Results of RT-PCR showed that E. amylovora WT prevents the transcript

Table 1. Accession numbers of cloned fragments of defense genes from Malus spp.

\begin{tabular}{ll}
\hline cDNA $^{\mathbf{a}}$ & \multicolumn{1}{c}{ Accession numbers } \\
\hline CHT & AF494395, AF494396, AF494397 \\
GLU & AF494404, AF494405 \\
PR-5 & AF494393, AF494394 \\
PAL & AF494403 \\
CHS & AF494401, AF494402 \\
CHI & AF494398, AF494399, AF494400 \\
DFR & AF494390, AF494391, AF494392 \\
FLS & AF494388, AF494389 \\
\hline
\end{tabular}

${ }^{\mathrm{a}} \mathrm{CHT}=$ chitinase, $\mathrm{GLU}=\beta$-1,3-glucanase, $\mathrm{PAL}=\mathrm{L}$-phenylalanine ammonia-lyase, $\mathrm{CHS}=$ chalcone synthase, $\mathrm{CHI}=$ chalcone isomerase, DFR $=$ dihydroflavonol reductase, and FLS $=$ flavonol synthase. 
accumulation of CHS, DFR, and FLS in both organs (Fig. 4) as it does in leaves. In these experiments, the high increase of transcript level of PR-5 (used as a positive control of transcription) by E. amylovora WT showed that progressively invaded tissues still were able to react to the pathogen.

\section{DISCUSSION}

In this article, we showed that E. amylovora induces in its host plants (either susceptible or resistant), and according to similar patterns, most of the defense mechanisms elicited by an incompatible necrogenic bacteria such as $P$. syringae pv. tabaci. However, we present evidence that the fire blight pathogen is able, especially in the susceptible genotype, to specifically prevent the expression of genes encoding some enzymes of various branch pathways of the phenylpropanoid metabolism. This ability appeared to be related to a functional Hrp-secretory apparatus of the bacteria.

Most of this study was performed with leaf tissues infiltrated with bacteria. Leaf infiltration is the only method which allows simultaneous challenge of a high number of plant cells with bacteria on intact plants and analysis of molecular responses. This is particularly true for situations where bacteria are not able to invade plant tissues (i.e., most of the plant-bacteria combinations used in this study). However, this method is somehow an artificial process to mimic the confrontation between bacteria and plant cells and its value, therefore, may be questionable. Some additional experiments then were performed on flowers and shoots of the susceptible genotype undergoing a natural progressive invasion of $E$. amylovora. They were conducted with inoculation procedures known to mimic natural infection (i.e., flower or wounded leaf infection, respectively). Their results validated the infiltration method as an experimental approach.

Using the leaf infiltration method we showed, in a previous work, that E. amylovora has the unexpected ability to generate in susceptible pear seedlings an oxidative stress similar to the one induced by the incompatible $P$. syringae pv. tabaci (Venisse et al. 2001). The present work deals with cultivars of Malus, another host genus of E. amylovora. The genus Malus was preferred to Pyrus for technical convenience. Apple scions showed better development of young growing shoots and leaves after grafting than pear scions, and extraction of proteins and RNA from leaves was easier for the former than for the latter. The first step of this work was to check the occurrence of an oxidative burst in Malus spp. after infection by $E$. amylovora and, furthermore, to compare this occurrence between a resistant and a susceptible genotype. In apple leaves infiltrated with the different bacterial strains, we indirectly assessed this phenomenon through the activation of APOX and

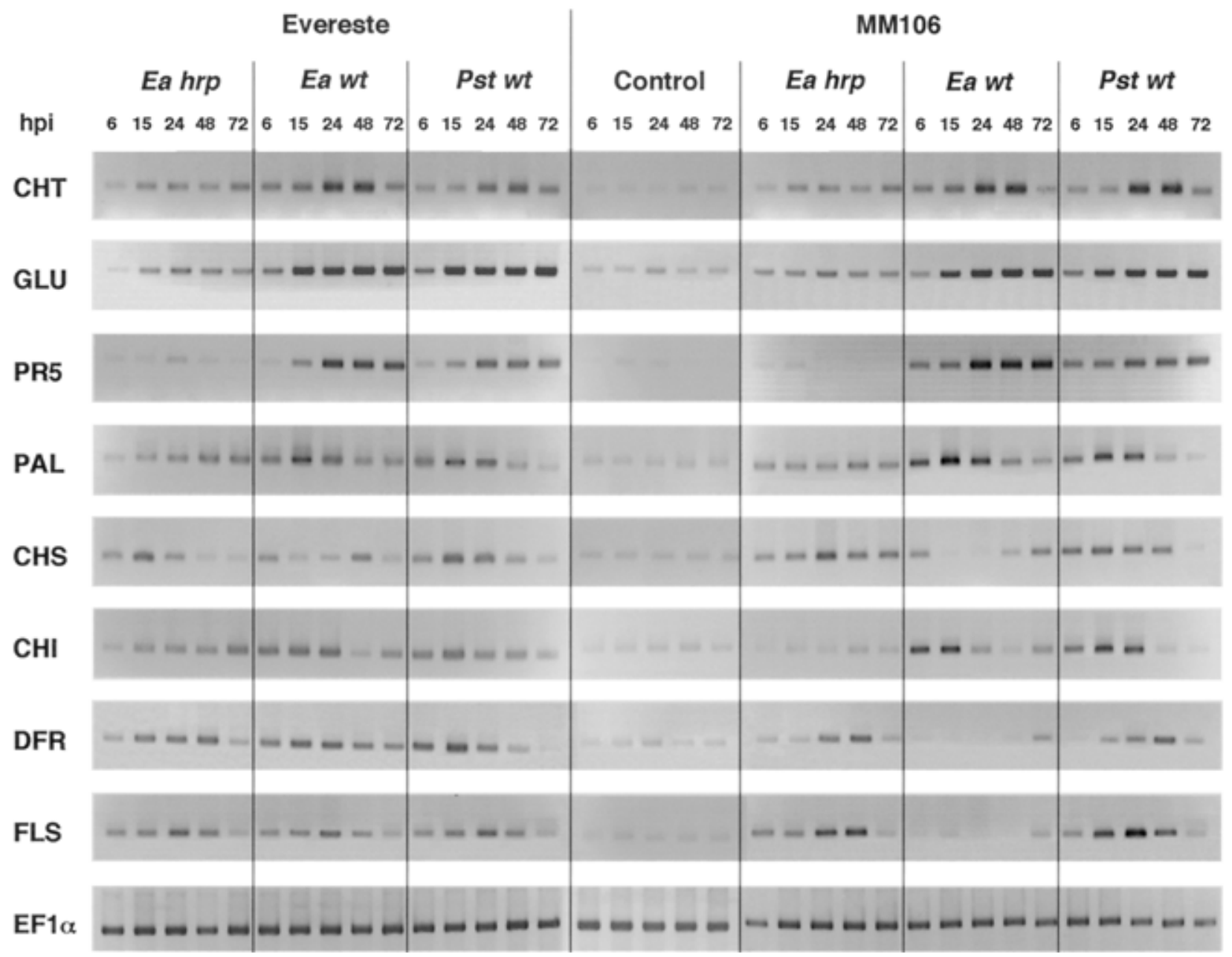

Fig. 3. Chitinase (CHT), $\beta$-1,3-glucanase (GLU), PR-5, L-phenylalanine ammonia-lyase (PAL), chalcone synthase (CHS), chalcone isomerase (CHI), dihydroflavonol reductase (DFR), and flavonol synthase (FLS) gene expression in leaves of the susceptible genotype MM106 and the resistant genotype Evereste infiltrated with bacterial suspensions $\left(10^{7} \mathrm{CFU} / \mathrm{ml}\right)$ of wild-type Erwinia amylovora CFBP1430 (Ea wt), its hrp secretion mutant PMV6023 (Ea hrp), and wild-type Pseudomonas syringae pv. tabaci CFBP2106 (Pst wt) or sterile distilled water (shown for MM106 only). Semiquantitative reversetranscription polymerase chain reaction-derived amplification products were separated on Tris-borate-EDTA agarose gels and stained with ethidium bromide. EF $1 \alpha=$ constitutive elongation factor $1 \alpha$ gene; hpi $=$ hours postinfiltration. Experiments repeated at least twice. Results of a typical experiment. 
GR, two enzymes of the ascorbate-glutathione cycle (Noctor and Foyer 1998). Indeed, a strong correlation exists between $\mathrm{O}_{2}{ }^{\circ-}$ generation, lipid peroxidation, and activation of antioxidative enzymes (Venisse et al. 2001). In the present work, the similar patterns of induction of APOX and GR observed in leaves of both apple genotypes infiltrated with E. amylovora WT and $P$. syringae pv. tabaci WT strongly suggest that $E$. amylovora induces an oxidative burst in apple, as it does in pear, and that this phenomenon, in the case of the fire blight pathogen, is not associated with an incompatible interaction only, as usually described in the literature (Lamb and Dixon 1997). The observation of $\mathrm{O}_{2}{ }^{\circ-}$ generation (as revealed by the reduction of NBT) in susceptible apple tissues (flower and shoot) progressively invaded by the pathogen definitely established the occurrence of an oxidative burst associated with fire blight infection. It also must be emphasized that the oxidative burst preceded necrosis development. This zone, beyond the necrotic area, is known to be the site where bacteria are actively multiplying. Our result reinforces the hypothesis previously stated (Venisse et al. 2001) that E. amylovora uses the oxidative burst as a driving force to kill plant cells and supply itself with nutrients.

Local activation of the phenylpropanoid metabolism and local and systemic accumulation of PR proteins already have been described in plants reacting hypersensitively to incompatible pathogens (Kombrick and Somssich 1995). Several comparative studies have shown that temporal or spatial patterns of defense-related gene expression may differ markedly between compatible and incompatible plant-pathogen interactions (Benhamou et al. 1989; Joosten and de Wit 1989; Pritsch

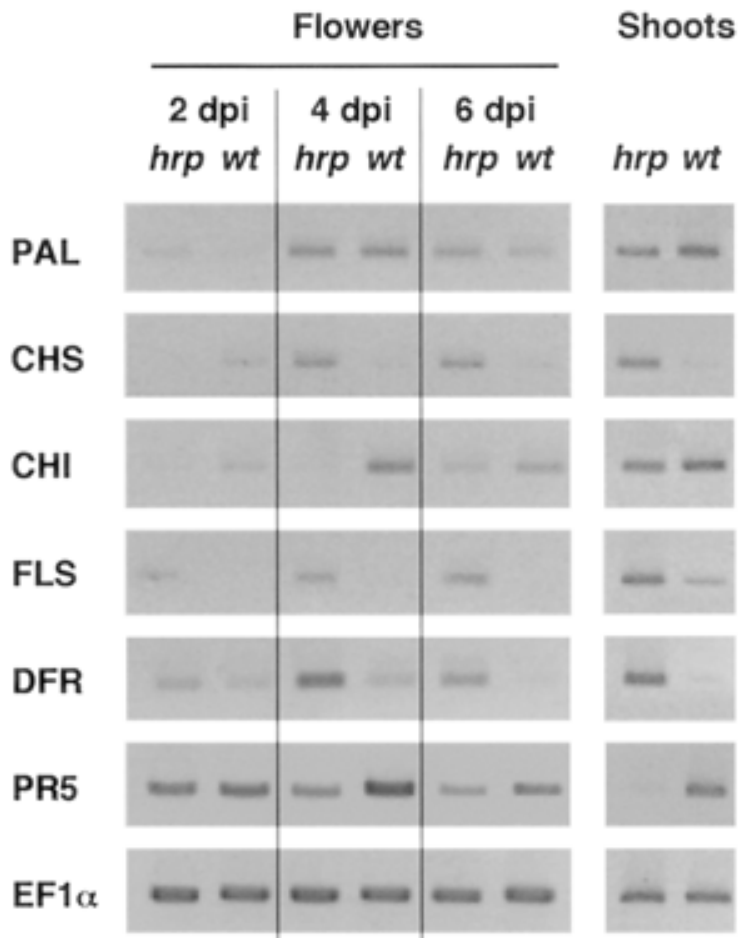

Fig. 4. L-phenylalanine ammonia-lyase (PAL), chalcone synthase (CHS), chalcone isomerase (CHI), dihydroflavonol reductase (DFR), flavonol synthase (FLS), and PR-5 gene expression in flowers and shoots of the susceptible genotype MM106 inoculated with wild-type Erwinia amylovora CFBP1430 (wt) and its hrp secretion mutant PMV6023 (hrp). RNAs were isolated from flowers sampled 2, 4, and 6 days post inoculation (dpi), and from shoots sampled $10 \mathrm{dpi}$. Semiquantitative reverse-transcription polymerase chain reaction-derived amplification products were separated on Tris-borate-EDTA agarose gels and stained with ethidium bromide. EF $1 \alpha=$ constitutive elongation factor $1 \alpha$ gene. Experiments repeated twice. Results of a typical experiment. et al. 2000; Reimers et al. 1992; Scott-Craig et al. 1995). However, other studies demonstrated a similar expression of some defense-related genes in both situations (Clark et al. 1995; Jakobek and Lindgren 1993; Ray and Hammerschmidt 1998; Schröder et al. 1992). This indicates that a defense-related gene is not systematically associated with a resistant phenotype. To further investigate the mechanisms that could underlie susceptibility or resistance to fire blight, we chose to compare a wide range of defense-related molecules in the different genotype-bacteria combinations tested.

As far as PR proteins are concerned, in leaves we found similar patterns of induction at the transcriptional or translational level for POX, GLU, CHT, and PR-5 in every plantbacteria interaction involving virulent wild-type strains. POX are known to be involved in plant cell wall reinforcement. According to our results, this phenomenon does not seem to be critical for E. amylovora for a successful colonization of susceptible leaf tissues. GLU, CHT, and PR-5 have been described as having mainly antifungal activities, although some chitinases also can display lysozyme activity and are able to hydrolyze bacterial peptidoglycan (Fritig et al. 1998). However, none of these antimicrobial defenses seems to impede $E$. amylovora in its susceptible hosts.

The various branch pathways of the phenylpropanoid metabolism lead to a large variety of compounds with diverse functions, including antimicrobial compounds and antioxidant protectants (various flavonoid compounds), signal molecules (salicylic acid), and structural components (precursors of lignin). This secondary metabolism then can be involved in the restriction of multiplication of the invading pathogen in several ways, such as direct pathogen death, balance of the oxidative status, reinforcement of the plant cell wall, and elicitation of SAR (Cooper-Driver and Bhattacharya 1998; Dixon and Paiva 1995).

Occurrence of phenolic compounds is well documented in fruit and leaves of apple (Macheix et al. 1990; Mayr et al. 1995; Treutter 2001). The main phenolics are phloretin and phloretin glycosides (dihydrochalcones); quercetin and quercetin glycosides (flavonols); catechin, epicatechin, and procyanidin (flavanols); and chlorogenic acid (hydroxycinnamic acid) (Fig. 5). The antibacterial activity of phloretin has been previously demonstrated in vitro against $E$. amylovora and its involvement in resistance to fire blight has been suggested (Addy and Goodman 1974). Catechin and epicatechin have been shown to exhibit in vitro high inhibitory activity against several phytopathogenic bacteria (Kodama et al. 1991). Quercetin, catechin, and epicatechin are known to have high antioxidative properties (Cooper-Driver and Bhattacharya 1998).

In this work, we showed that E. amylovora seems to be able to specifically and transiently prevent the transcription of several isoforms of CHS, DFR, and FLS genes when infiltrated in leaves of the susceptible genotype MM106. These genes, as well as PAL and CHI genes, were, by contrast, induced in every other plant-bacteria interactions involving wild-type strains. The ability of E. amylovora to prevent the transcription of CHS, DFR, and FLS genes during the compatible situation was further confirmed in flowers and shoots undergoing a progressive invasion of E. amylovora. According to the biosynthesis of phenolic compounds, the lack of expression of CHS, DFR, and FLS genes should lead to a decrease of synthesis of at least the four main end products: phloretin, quercetin, catechin, and epicatechin. Although we cannot exclude the possibility that other isoforms of these genes (not detected with our probes) are, by contrast, induced by the bacteria, our results suggest that E. amylovora benefits from the prevention of the accumulation of various flavonoids for a successful patho- 
genesis, either in escaping their potential antibacterial action or in preventing the establishment of a high antioxidant status which could counteract the damaging effect of reactive oxygen intermediates needed by the bacteria for the invasion of plant tissues. The validation of this hypothesis could be performed by the direct quantification of phenolic compounds in apple leaves challenged by E. amylovora.

This hypothesis is strengthened by results obtained with the resistant genotype Evereste. Although most transcript levels were similar in both genotypes, no repression of CHS, DFR, and FLS gene expression was observed in Evereste after leaf infiltration with E. amylovora WT. Also, a higher constitutive level of GR was observed compared with the susceptible genotype. In addition, it has been shown (Sierotski and Gessler 1993) that Evereste accumulates very high constitutive levels of flavan-3-ols (catechin and epicatechin) compared with other apple cultivars. On the whole, these results suggest that the resistance of Evereste could, at least partially, rely on a high constitutive antioxidant status of either enzymatic or nonenzymatic origin (or even on a high constitutive antibacterial status), keeping active oxygen (or even bacteria) under control conversely to the susceptible genotype MM106. However, it cannot be ruled out that the resistant phenotype of Evereste might involve additional mechanisms.

An hrp secretory mutant of E. amylovora was included as a negative bacterial control in our experiments. We previously demonstrated that this avirulent mutant was unable to elicit any oxidative burst in pear (Venisse et al. 2001). The same seems to be true in apple, because antioxidative enzymes were not activated in leaves challenged with this mutant. This confirms that the oxidative burst is triggered by Hrp-secreted proteins. Among the various other defense mechanisms studied, some remained at a very low level after infiltration of the hrp mutant (POX, GLU, CHT, PR-5, PAL, and CHI), suggesting that they also are triggered (directly or indirectly) by Hrpeffectors.

By contrast, some other mechanisms (CHS, DFR, and FLS) were induced by the hrp mutant at levels similar to those induced by the incompatible bacteria $P$. syringae pv. tabaci in both genotypes, whereas they were induced tardily by the wild-type strain of E. amylovora in the susceptible genotype. This suggests the existence in E. amylovora of an hrp gene-independent mechanism for the induction of the genes encoding these different enzymes. Such induction of defense-related responses that are $h r p$-independent already have been observed in other plant-bacteria interactions involving $P$. syringae (Jakobek and Lindgren 1993) and X. campestris (Brown et al. 1995; Kamoun et al. 1992; Newman et al. 2001). Various external bacterial components which could act as nonspecific elicitors have been proposed, such as lipopolysaccharides (Dow et al. 2000), flagellin (Felix et al. 1999), or proteins that are not secreted by the Hrp system (Palva et al. 1993). The same kind of nonspecific elicitors could be proposed for $E$. amylovora. The rapid induction of CHS, FLS, and DFR genes observed in apple tissue challenged with the hrp secretory mutant of E. amylovora compared with the delayed induction of these genes observed in susceptible tissue challenged by the wild-type strain also suggests the existence in E. amylovora of hrp-dependant mechanisms to suppress or at least to modulate these nonspecific inductions. As mentioned in the introduction, such $h r p$-dependant mechanisms of suppression already have been proposed in the case of $P$. syringae and $X$. campestris (Brown et al. 1995; Jakobek et al. 1993; Kamoun et al. 1992; Newman et al. 2001). However, the identity of the suppressors are still unknown.

In conclusion, we showed that E. amylovora elicits in its host plants many early events usually ascribed to incompatible inter- actions. In contrast, some specific mechanisms are suppressed, especially in a susceptible genotype. According to these results, the following hypothetical model of interaction can be suggested: E. amylovora induces two groups of responses in its host plants. One group is triggered after the action of Hrp-secreted proteins, including an oxidative burst, necessary for pathogenesis, and subsequent defense mechanisms with no incidence on the bacteria. A second group is triggered by nonspecific hrpindependent bacterial elicitors, with negative effects on the pathogenesis, the bacteria, or both. This group needs to be suppressed by additional Hrp-secreted proteins for a successful pathogenesis. The identity of nonspecific elicitors as well as of suppressors remains to be determined.

\section{MATERIALS AND METHODS}

\section{Plant materials and growth conditions.}

Two Malus $\times$ domestica genotypes were chosen for their contrasted susceptibility to fire blight: the rootstock MM106, very susceptible (Huet and Michelesi 1990), and the ornamental Evereste, resistant (Thibault and Le Lézec 1990). For leaf studies, experiments were performed on young grafted scions on MM106 rootstock grown in individual pots in the greenhouse at temperatures between 17 and $22^{\circ} \mathrm{C}$ under a natural photoperiod. Plants were pre-incubated overnight at $25^{\circ} \mathrm{C}$ in light conditions and under high relative humidity before leaf infiltration. For flower studies, branches of apple

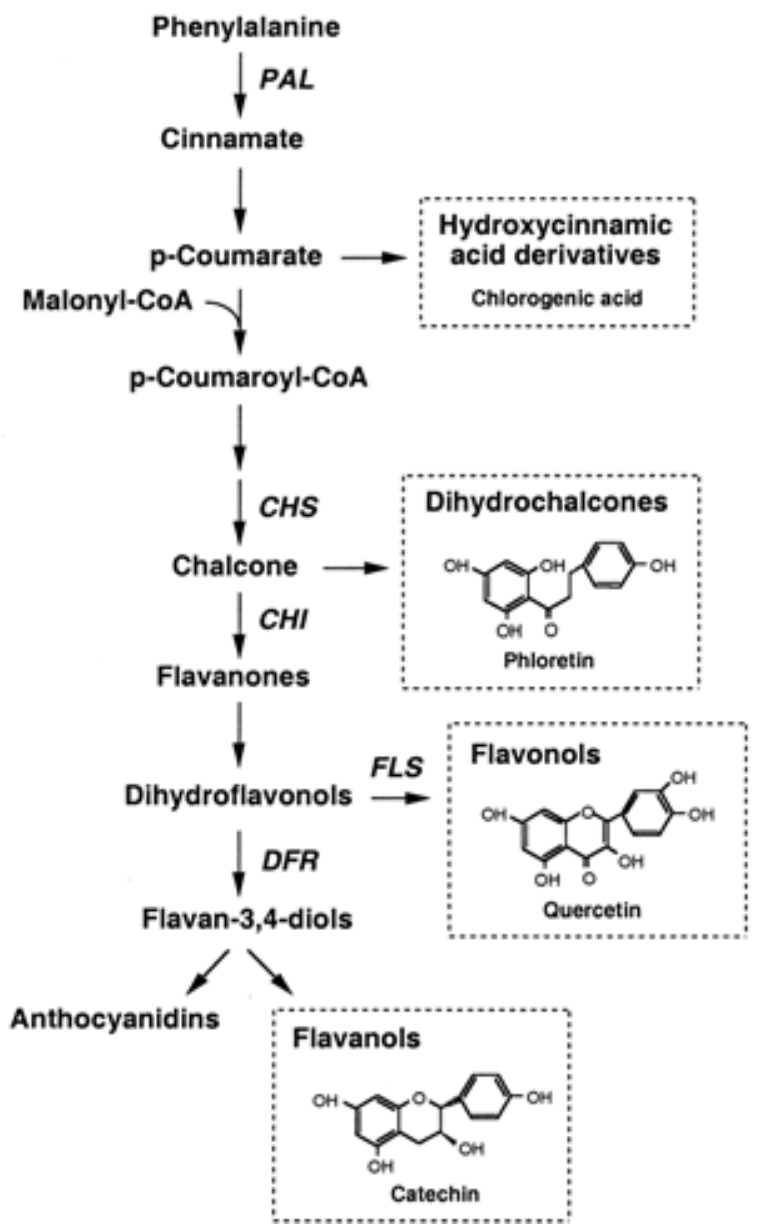

Fig. 5. Schematic representation of the phenylpropanoid pathway in Malus spp. (after Treutter 2001 and D. Treutter, personal communication). $\mathrm{PAL}=\mathrm{L}$-phenylalanine ammonia-lyase, $\mathrm{CHS}=$ chalcone synthase, $\mathrm{CHI}=$ chalcone isomerase, DFR = dihydroflavonol reductase, and FLS = flavonol synthase. 
trees were collected from the orchard and placed in buckets filled with water in the greenhouse. The flowers were handpollinated and inoculated $24 \mathrm{~h}$ later.

\section{Bacterial strains and inoculation procedures.}

Bacterial strains used were E. amylovora CFBP1430 and $P$. syringae pv. tabaci CFBP2106, two wild-type strains from the Collection Française de Bactéries Phytopathogènes, INRA, Angers, and PMV6023, an hrp secretion transposon mutant derivative of E. amylovora WT (Barny 1995). Bacteria were subcultured at $27^{\circ} \mathrm{C}$ for $18 \mathrm{~h}$ on solid King's medium B (King et al. 1954) supplemented with chloramphenicol $(20 \mu \mathrm{g} / \mathrm{ml})$ for the mutant. Bacterial inocula were prepared in sterile distilled water to yield a concentration of $10^{7} \mathrm{CFU} / \mathrm{ml}$. For leaf studies, the three youngest expanded leaves of each apple scion were inoculated by vacuum infiltration. For shoot studies, the youngest expanded leaf of each grafted shoot was wounded by a double incision perpendicular to the midrib and a drop (10 $\mu \mathrm{l})$ of bacterial suspension was deposited on the wound. Apple flowers were inoculated with a $30-\mu l$ droplet of bacterial suspension inserted carefully onto the hypanthium.

\section{$\mathrm{O}_{2}{ }^{\circ-}$ staining.}

Among ROS products, $\mathrm{O}_{2}{ }^{\circ-}$ specifically was detected using NBT according to the method described by Doke and associates (1983). Flowers and stems from MM106 were cut longitudinally and vacuum infiltrated with a solution of $0.5 \%$ (wt/vol) NBT. After $30 \mathrm{~min}$ of staining at room temperature under light, the NBT-treated tissues were placed in $96 \%$ ethanol to stop reaction and pictures were taken immediately.

\section{Assays for enzymatic activities.}

Enzymes were extracted by grinding $200 \mathrm{mg}$ of fresh leaves into $2 \mathrm{ml}$ of the extraction buffer described in Venisse and associates (2001) for APOX and GR studies, or into $2 \mathrm{ml}$ of 50 $\mathrm{mM}$ sodium acetate buffer $(\mathrm{pH} 5.5)$ containing $1 \mathrm{mM}$ polyethyleneglycol, $1 \mathrm{mM}$ phenylmethylsulfonyl fluoride, $8 \%$ (wt/vol) polyvinypolypyrolidone, and $0.01 \%$ (vol/vol) triton X-100 for POX, CHT, and GLU studies. Homogenates were centrifuged at $16,000 \times g$ at $4^{\circ} \mathrm{C}$ for $20 \mathrm{~min}$ and supernatants were used immediately for enzymatic activity assays. The activities of each enzyme were colorimetrically assayed. APOX, GR, and POX activities were determined according to the methods of Nakano and Asada (1981), Halliwell and Foyer (1978), and Chance and Maehly (1955), respectively, with some modifications (Venisse et al. 2001). CHT and GLU were assayed according to the method of Wirth and Wolf (1992) with some modifications. Carboxymethyl-curdlan-Remazol Brilliant Violet (CM-curdlan-RBV) and carboxymethylcurdlan-Remazol Brilliant Blue (CM-curdlan-RBB) were used as their respective substrates (Loewe Biochemica, Otterfing, Germany). Then, $100 \mu \mathrm{l}$ of CM-curdlan-RBV $(200 \mu \mathrm{g} / \mathrm{ml})$ or CM-curdlan-RBB $(400 \mu \mathrm{g} / \mathrm{ml})$ were prepared in sodium acetate buffer (vol/vol, $200 \mathrm{mM}, \mathrm{pH} 5$ ), pre-incubated at $37^{\circ} \mathrm{C}$ for $10 \mathrm{~min}$, and then mixed to $200 \mu \mathrm{l}$ of crude supernatant. The mixture was incubated at $37^{\circ} \mathrm{C}$ for $30 \mathrm{~min}$ and immediately stopped by addition of $100 \mu \mathrm{l}$ of $2 \mathrm{~N} \mathrm{HCl}$. For the reference, the reaction was stopped immediately with $\mathrm{HCl}$ after the addition of the substrate. Nondigested substrate was precipitated after $10 \mathrm{~min}$ of incubation on ice, then separated from the digested substrate by centrifugation at $10,000 \times g$ for $10 \mathrm{~min}$. CHT and GLU activities were calculated from the difference of absorbance (550 and $600 \mathrm{~nm}$, respectively) between the incubated sample and reference. Data were expressed as the increase of absorbance per minute and per milligram of protein.

Protein content in the crude enzyme extracts was determined according to the method of Bradford (1976) using Coomassie Protein Assay Reagent (Pierce, Rockford, IL, U.S.A.).

All experiments were performed with a minimum of three tissue samples replicated per treatment and per time point. Each experiment was performed at least two times and data are expressed as the means $( \pm \mathrm{SE})$.

\section{RNA extraction.}

Apple tissues (approximately $250 \mathrm{mg}$ ) were ground to a fine powder in liquid nitrogen and transferred into $1 \mathrm{ml}$ of lysis buffer (10 mM Tris-HCl, pH 7.5, $50 \mathrm{mM} \mathrm{MgCl}$, $5 \%$ [wt/vol] sodium dodecyl sulfate). The homogenate was incubated for $10 \mathrm{~min}$ at $60^{\circ} \mathrm{C}$, cooled $5 \mathrm{~min}$ at room temperature, and treated with $500 \mu \mathrm{l}$ of potassium acetate ( $3 \mathrm{M}, \mathrm{pH} 5)$. After an incubation $(2 \mathrm{~min})$ at room temperature, tissue debris were removed by centrifugation $\left(15 \mathrm{~min}, 10,000 \times g\right.$ at $\left.4^{\circ} \mathrm{C}\right)$. One volume of isopropanol was added to the supernatant. The mixture was incubated one hour at $-20^{\circ} \mathrm{C}$, then centrifuged $15 \mathrm{~min}$ at 16,000 $\times g$ at $4^{\circ} \mathrm{C}$. The pellet was resuspended in $200 \mu$ l of water treated with DEPC (1\%o, vol/vol) supplemented by $20 \mu \mathrm{lof}$ $100 \%$ ethanol and incubated $10 \mathrm{~min}$ in ice. After a centrifugation, $5 \mathrm{~min}$ at $15,000 \times g$ at $4^{\circ} \mathrm{C}$, the supernatant was collected

Table 2. Primer sequences used for polymerase chain reaction

\begin{tabular}{|c|c|c|c|c|}
\hline cDNA $^{\mathrm{a}}$ & Degenerated primer sequence $^{b}$ & Specific Malus spp. primer sequence & $\operatorname{Tm}\left({ }^{\circ} \mathbf{C}\right)$ & Size (bp) \\
\hline \multirow[t]{2}{*}{ CHT } & fo 5'-CNY CAA ACT TCM CAT GAA AC-3' & fo 5'-GGT CAA ACT TCT CAT GAA AC-3' & & \\
\hline & re 5'-GGK GTC ATC CAG AAC CA-3' & re 5'-GGG GTC ATC CAG AAC CA-3' & 50 & 293 \\
\hline \multirow[t]{2}{*}{ GLU } & fo 5'-TAT GNT CTT VTC ACA GCA CCG-3' & fo 5'-TAT GCT CTT TTC ACA GCT CCG-3' & & \\
\hline & re 5'-CAA TGT TTC TCA AGC TCT GG-3' & re 5'-CAA TGT TTC TCA AGC TCT GG-3' & 50 & 320 \\
\hline \multirow[t]{2}{*}{ PR-5 } & fo 5'-AAC ACN GTN TGG CCA GGA ACC-3' & fo 5'-AAC ACT GTT TGG CCA GGA ACC-3' & & \\
\hline & re 5'-GTT GAA GNC GTC NAC AAG GG-3' & re 5'-GTT GAA GCC GTC AAC AAG GC-3' & 55 & 309 \\
\hline \multirow[t]{2}{*}{ PAL } & 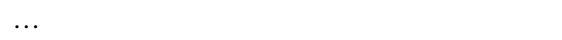 & fo 5'-GAG GCA TTT GGA GGA GAA CTT G-3' & & \\
\hline & & re 5'-TCA ACC TCT TAA GGC AAA AGC GC-3' & 50 & 301 \\
\hline \multirow[t]{2}{*}{ CHS } & fo 5'-ATC ACN GCN GTN ACC TTC CG-3' & fo 5'-CTA GTG ACA CCC ACC TTG ACA-3' & & \\
\hline & re 5'-CAN GCA CTN GAC ATG TTN CC-3' & re 5'-CAG AAT AGC AGG GCC ACC TG-3' & 50 & 442 \\
\hline \multirow[t]{2}{*}{$\mathrm{CHI}$} & fo $5^{\prime}$-GRG ACA TMG TYA CAG GTC C-3' & fo $5^{\prime}$-TTC AAG TGA CAA CGA TAC TGC C-3' & & \\
\hline & re 5'-CTT TGN TMC AGG NGA AAC ACC-3' & re 5'-CGA TCG ACT CTA GAA CTG CC-3' & 50 & 362 \\
\hline \multirow[t]{2}{*}{ DFR } & fo 5'-TGA CYG GTT GGA TGT AYT TCG-3' & fo $5^{\prime}$-TGA CCG GTT GGA TGT ACT TCG-3' & & \\
\hline & re 5'-GAS GAR CAA ATN TAA CGG CC-3' & re 5'-GAG GAG CAA ATG TAA CGG CC-3' & 55 & 290 \\
\hline \multirow[t]{2}{*}{ FLS } & fo $5^{\prime}$-TAC YCA CCR TGT CCT CGN CC-3' & fo $5^{\prime}$-TAC CCA CCA TGT CCT CGC CC-3' & & \\
\hline & re 5'-GGC TCC AAG AAM ACN GGC C-3' & re 5'-GGC TCC AAG AAC ACA GGC C-3' & 55 & 288 \\
\hline \multirow[t]{2}{*}{$\mathrm{EF} 1 \alpha$} & fo 5'-ATT GTG GTC ATT GGY CAY GT-3' & & & \\
\hline & re 5'-CCT ATC TTG TAV ACA TCC TG-3' & $\ldots$ & 50 & 700 \\
\hline
\end{tabular}

${ }^{\mathrm{a}} \mathrm{CHT}=$ chitinase, $\mathrm{GLU}=\beta-1,3$-glucanase, $\mathrm{PAL}=\mathrm{L}$-phenylalanine ammonia-lyase, $\mathrm{CHS}=$ chalcone synthase, $\mathrm{CHI}=$ chalcone isomerase, $\mathrm{DFR}=$ dihydroflavonol reductase, FLS $=$ flavonol synthase, and EF $1 \alpha=$ elongation factor $1 \alpha$.

${ }^{\mathrm{b}}$ Degenerate nucleotides: fo $=$ forward, $\mathrm{re}=$ reverse, $\mathrm{K}=\mathrm{G}$ or T; $\mathrm{M}=\mathrm{A}$ or $\mathrm{C} ; \mathrm{R}=\mathrm{A}$ or $\mathrm{G} ; \mathrm{S}=\mathrm{G}$ or $\mathrm{C} ; \mathrm{V}=\mathrm{G}$ or $\mathrm{T} ; \mathrm{W}=\mathrm{A}$ or $\mathrm{T} ; \mathrm{Y}=\mathrm{C}$ or $\mathrm{T} ; \mathrm{N}=\mathrm{A}, \mathrm{T}, \mathrm{C}$ or $\mathrm{G}$. 
and was treated overnight at $-20^{\circ} \mathrm{C}$ with $80 \mu \mathrm{l}$ of $\mathrm{LiCl}(10 \mathrm{M})$. The precipitate was collected by centrifugation at $16,000 \times g$ at $4{ }^{\circ} \mathrm{C}$ for $30 \mathrm{~min}$ and was washed by $3 \mathrm{M} \mathrm{LiCl}$ and by $80 \%$ ethanol, then dissolved in $60 \mu$ of water (DEPC) before being treated with $10 \mathrm{U}$ RNAse free-DNAse (Promega, Madison, WI, U.S.A.) for $30 \mathrm{~min}$. After phenol-chloroform ( $\mathrm{vol} / \mathrm{vol}$ ) and chloroform ( $\mathrm{vol} / \mathrm{vol})$ washes, total RNA was precipitated with $100 \%$ ethanol $(2 \mathrm{~V})$ and ammonium acetate $7.5 \mathrm{M}(0.5 \mathrm{~V})$ overnight at $-20^{\circ} \mathrm{C}$. After centrifugation at $16,000 \times g$ at $4^{\circ} \mathrm{C}$ for $30 \mathrm{~min}$, the pellet was washed with $80 \%$ ethanol, dissolved in $55 \mu \mathrm{l}$ of water (DEPC), and stored at $-80^{\circ} \mathrm{C}$ for further analysis. Total RNA quality and concentration of each sample were assessed spectrophotometrically by measuring the absorbance at 280,260, and $230 \mathrm{~nm}$ and after running on agarose gel $(1.2 \% \mathrm{wt} / \mathrm{vol})$ and staining with ethydium bromide $(10 \mathrm{mg}$ per liter).

\section{RT-PCR experiments.}

First-strand cDNA was synthesized using total RNA $(2 \mu \mathrm{g})$ in a volume of $30 \mu \mathrm{l}$ of $5 \times$ buffer (Promega), $1 \mu \mathrm{g}$ of oligodT15 primer, $5 \mu \mathrm{l}$ of dNTPs $(10 \mathrm{nM})$, and 150 units of MMLV RTase (Promega). The mixture was further incubated at $42^{\circ} \mathrm{C}$ for $75 \mathrm{~min}$. PCR amplifications were carried out using appropriate primers (Table 2). In all, $2 \mu$ l of cDNA was used per $40 \mu \mathrm{l}$ of PCR mix containing $4 \mu \mathrm{l}$ of $10 \times$ PCR buffer, $1 \mu \mathrm{l}$ of dNTPs mix (2.5 mM each), $0.5 \mu \mathrm{l}$ of forward primers $(10$ $\mu \mathrm{M}), 0.5 \mu \mathrm{l}$ of reverse primers $(10 \mu \mathrm{M})$, and $0.1 \mu \mathrm{l}$ of Taq polymerase (5 U) (Q.BIOgene, Illkirch, France). PCR cycling conditions were an initial step of $4 \mathrm{~min}$ at $94^{\circ} \mathrm{C}$ followed by 25 to 35 cycles (according to the experiments, see below) of $45 \mathrm{~s}$ at $94^{\circ} \mathrm{C}, 1 \mathrm{~min}$ at $\mathrm{Tm}^{\circ} \mathrm{C}$ (Table 2 ), $1 \mathrm{~min}$ at $72^{\circ} \mathrm{C}$, and a final step of $15 \mathrm{~min}$ at $72^{\circ} \mathrm{C}$.

\section{Cloning fragments \\ of defense genes from Malus spp. by PCR.}

Multiple sequence alignment (using Network Protein Sequence software; NPS, Lyon, France) of defense genes of Malus spp. and other plant species listed in GenBank databases at the National Center for Biological Information (NCBI, Bethesda, MD, U.S.A.) were performed. Primers were designed within regions highly conserved to produce RT-PCR products that were in the range of 270 to $700 \mathrm{bp}$ and allowing annealing at 50 or $55^{\circ} \mathrm{C}$. Most of them were degenerated, except PAL primers (Table 2). From reverse-transcripted mRNA, PCR amplification were carried out using these primers and PCR cycling conditions described above with 35 cycles. The resulting PCR products were purified and subcloned in pGEMT-easy (Promega) according to the manufacturer's protocol. For each set of primers, a restriction analysis of 20 resulting recombinant plasmids chosen at random was performed and the DNA inserts from clones showing different restriction patterns were sequenced (MWG Biotech, Courtaboeuf, France). Sequence data were analyzed by the NCBI BLAST server.

\section{Defense gene expression.}

Upon sequence verification, nondegenerate matching primers ("specific primers", Table 2) were designed. Global expression of each family of defense genes was analyzed by semi-quantitative PCR using these specific primers and PCR cycling conditions described above with 25 cycles, after checking that exponential increase of PCR products was still recorded after 35 cycles. Amplification of the translation elongation factor $1 \alpha(E f 1 \alpha)$ (Mahé et al. 1992) was used to adjust initial amounts of reverse-transcripted mRNA of each sample in PCR reaction in order to obtain an equivalent exponential amplification signal. Although Ef-1 $\alpha$ transcript levels were described to be developmentally and environmentally regulated in apple plants (Watillon et al. 1998), this gene can be considered as constantly expressed in our experiments because comparable plant organs were sampled in the same environmental conditions. In addition, Ef- $1 \alpha$ primers, previously designed to span an intron sequence (Rosati et al. 1997), allowed us to check the absence of genomic contamination. Amplification products of defense genes and the $E F-1 \alpha$ gene were separated on Tris HCl-borate-EDTA (1 M) agarose gels ( $2 \% \mathrm{wt} / \mathrm{vol})$ and stained with ethydium bromide (10 $\mathrm{mg} /$ liter). All samples resulted from the mixture of three tissue replicates per treatment and per time point and each experiment was performed at least twice. Similar results were obtained and representative data are shown.

\section{ACKNOWLEDGMENTS}

This work was partly supported by the Etablissement Public Régional, Pays de Loire, France. We thank Isabelle Pontais for excellent technical assistance, and Andrew Painter and Peter Neumann for careful reading of the manuscript.

\section{LITERATURE CITED}

Addy, S. K., and Goodman, R. N. 1974. Phenols in relation to pathogenesis induced by avirulent and virulent strains of Erwinia amylovora. Acta Phytopathol. Hung. 9:277-286.

Barny, M. A. 1995. Erwinia amylovora hrpN mutants, blocked in harpin synthesis, express a reduced virulence on host plants and elicit variable hypersensitive reactions on tobacco. Eur. J. Plant Pathol. 101:333-340.

Benhamou, N., Greiner, J., Asselin, A., and Legrand, M. 1989. Immunogold localization of $\beta-1,3$-glucanases in two plants infected by vascular wilt fungi. Plant Cell 1:1209-1221.

Bogdanove, A. J., Bauer, D. W., and Beer, S. V. 1998. Erwinia amylovora secretes DspE, a pathogenicity factor and functional AvrE homologue, through the Hrp (type III secretion) pathway. J. Bacteriol. 180:22442247.

Bradford, M. M. 1976. A rapid and sensitive method for quantitation of microgram quantities of protein utilizing the principle of protein-dye binding. Anal. Biochem. 72:248-254.

Brown, I., Mansfield, J., and Bonas, U. 1995. hrp genes in Xanthomonas campestris pv. vesicatoria determine ability to suppress papilla deposition in pepper mesophyll cells. Mol. Plant-Microbe Interact. 8:825-836.

Bugert, P., and Geider, K. 1995. Molecular analysis of the ams operon required for exopolysaccharide synthesis of Erwinia amylovora. Mol. Microbiol. 15:917-933.

Chance, B., and Maehly, A. C. 1955. Assay of catalases and peroxidases. Methods Enzymol. 2:764-775.

Clark, T. A., Zeyen, R. J., Carver, T. L. W., Smith, A. G., and Bushnell, W. R. 1995. Epidermal cell cytoplasmic events and response gene transcript accumulation during Erysiphe graminis attack in isogenic barley lines differing at the Mlo locus. Physiol. Mol. Plant Pathol. 46:1-17.

Cooper-Driver, G. A., and Bhattacharya, M. 1998. Role of phenolics in plant evolution. Phytochemistry 49:1165-1174.

Cornelis, G. R., and van Gijsegem, F. 2000. Assembly and function of type III secretory systems. Annu. Rev. Microbiol. 54:735-774.

Dellagi, A., Brisset, M. N., Paulin, J. P., and Expert, D. 1998. Dual role of desferrioxamine in Erwinia amylovora pathogenicity. Mol. PlantMicrobe Interact. 11:734-742.

Dixon, R. A., and Paiva N. L. 1995. Stress-induced phenylpropanoid metabolism. Plant Cell 7:1085-1097.

Doke, N. 1983. Involvement of superoxide anion generation in the hypersensitive response of potato tuber tissues to infection with an incompatible race of Phytophthora infestans and to the hyphal wall components. Physiol. Plant Pathol. 23:345-357.

Dow, M., Newman, M. A., and von Roepenack, E. 2000. The induction and modulation of plant defense responses by bacterial lipopolysaccarides. Annu. Rev. Phytopathol. 38:241-261.

Felix, G., Duran, J. D., Volko, S., and Boller, T. 1999. Plants have a sensitive perception system for the most conserved domain of bacterial flagellin. Plant J. 18:265-276.

Fritig, B., Heitz, T., and Legrand, M. 1998. Antimicrobial proteins in induced plant defense. Curr. Opin. Immunol. 10:16-22.

Gaudriault, S., Brisset, M. N., and Barny, M. A. 1998. HrpW of Erwinia amylovora, a new Hrp-secreted protein. FEBS Lett. 428:224-228.

Gaudriault, S., Malandrin, L., Paulin, J. P., and Barny, M. A. 1997. DspA, 
an essential pathogenicity factor of Erwinia amylovora showing homology with AvrE of Pseudomonas syringae, is secreted via Hrp secretion pathway in a DspB dependent way. Mol. Microbiol. 26:1057-1069.

Halliwell, B., and Foyer, C. H. 1978. Properties and physiological function of a glutathione reductase purified from spinach leaves by affinity chromatography. Planta 139:9-17

Hammond-Kosack, K. E., and Jones, J. D. G. 1996. Resistance gene-dependant plant defense responses. Plant Cell 8:1773-1791.

Huet, J., and Michelesi, J. C. 1990. Sensibilité au feu bactérien des principaux porte-greffe du poirier et du pommier utilisés en Europe. Pages 116-118 in: Fire Blight of Pomoideae (Erwinia amylovora, Burrill, Winslow et al.). Applied Research in Europe (1978-1988). EUR 12601 ECSC-EEC-EAEC, Brussels, Luxembourg.

Hutcheson, S. W. 1998. Current concepts of active defense in plants. Annu. Rev. Phytopathol. 36:59-90.

Jakobek, J. L., and Lindgren, P. B. 1993. Generalized induction of defense responses in bean is not correlated with the induction of the hypersensitive response. Plant Cell 5:49-56.

Jakobek, J. L., Smith, J. A., and Lindgren, P. B. 1993. Suppression of bean defense responses by Pseudomonas syringae. Plant Cell 5:57-63.

Jin, Q., Hu, W., Brown, I., McGhee, G., Hart, P., Jones, A. L., and He, S. Y. 2001. Visualization of secreted Hrp and Avr proteins along the Hrp pilus during type III secretion in Erwinia amylovora and Pseudomonas syringae. Mol. Microbiol. 40:1129-1139.

Joosten, M. H. A. J., and De Wit, P. J. D. M. 1989. Identification of several pathogenesis-related proteins in tomato leaves inoculated with Cladosporium fulvum as 1,3- $\beta$-glucanases and chitinases. Plant Physiol. 89:945-961.

Kamoun, S., Kamdar, H. V., Tola, E., and Kado, C. I. 1992. Incompatible interactions between crucifers and Xanthomonas campestris involve a vascular hypersensitive response: Role of the hrpX locus. Mol. PlantMicrobe Interact. 5:22-33.

Kim, J. F., and Beer, S. V. 1998. HrpW of Erwinia amylovora, a new harpin that contains a domain homologous to pectate lyases of a distinct class. J. Bacteriol. 180:5203-5210.

Kim, J. F., and Beer, S. V. 2000. hrp genes and harpins of Erwinia amylovora: A decade of discovery. Pages 141-161 in: Fire Blight, the Disease and Its Causative Agent, Erwinia amylovora. J. L. Vanneste, ed. CABI Publishing, Wallingford, U.K.

King, E. O., Ward, M. K., and Raney, D. E. 1954. Two simple media for the demonstration of pyocyanin and fluorescein. J. Lab. Clin. Med. 44:301-307.

Kodama, K., Sagesaka, Y., and Goto, M. 1991. Antimicrobial activities of catechins against plant pathogenic microorganisms. Pages 294-298 in: Proceed. ISTS, August 26-29, 1991, Shizuoka, Japan.

Kombrink, E., and Somssich, I. E. 1995. Defense responses of plants to pathogens. Adv. Bot. Res. 21:1-34.

Lamb, C., and Dixon, R. A. 1997. The oxidative burst in plant disease resistance. Annu. Rev. Plant Physiol. Plant Mol. Biol. 48:251-275.

Macheix, J. J., Fleuriet, A., and Billot, J. 1990. Fruit Phenolics. CRC Press, Boca Raton, FL.

Mahé, A., Grisvard, J., and Dron, M. 1992. Fungal and specific gene markers follow the bean anthracnose infection process and normalize a bean chitinase mRNA induction. Mol. Plant-Microbe Interact. 5:242-248.

Mayr, U., Treutter, D., Santos-Buelga, C., Bauer, H., and Feucht, W. 1995. Developmental changes in the phenol concentrations of 'Golden Delicious' apple fruits and leaves. Phytochemistry 38:1151-1155.

Nakano, Y., and Asada, K. 1981. Hydrogen peroxide is scavenged by ascorbate-specific peroxidase in spinach chloroplasts. Plant Cell
Physiol. 22:867-880

Newman, M. A., von Roepenack-Lahaye, E., Parr, A., Daniels, M. J., and Dow, J. M. 2001. Induction of hydroxycinnamoyl-tyramine conjugates in pepper by Xanthomonas campestris, a plant defense response activated by hrp gene-dependant and hrp gene-independent mechanisms. Mol. Plant-Microbe Interact. 14:785-792.

Noctor, G., and Foyer, C. H. 1998. Ascorbate and glutathione: Keeping active oxygen under control. Annu. Rev. Plant Physiol. Plant Mol. Biol. 49:249-279.

Palva, T. K., Holmström, K. O., Heino, P., and Palva, E. T. 1993. Induction of plant defense response by exoenzymes of Erwinia carotovora subsp. carotovora. Mol. Plant-Microbe Interact. 6:190-196.

Pritsch, C., Muehlbauer, G. J., Bushnell, W. R., Somers, D. A., and Vance, C. P. 2000. Fungal development and induction of defense response genes during early infection of wheat spikes by Fusarium graminearum. Mol. Plant-Microbe Interact. 13:159-169.

Ray, H., and Hammerschmidt, R. 1998. Responses of potato tuber to infection by Fusarium sambucinum. Physiol. Mol. Plant Pathol. 53:81-92.

Reimers, P. J., Guo, A., and Leach, J. E. 1992. Increased activity of a cationic peroxidase associated with an incompatible interaction between Xanthomonas oryzae pv. oryzae and rice. Plant Physiol. 99:1044-1050.

Rosati, C., Cadic, A., Duron, M., Renou, J. P., and Simoneau, P. 1997. Molecular cloning and expression analysis of dihydroflavonol-4-reductase gene in flower organs of Forsythia x intermedia. Plant Mol. Biol. 35:303-311.

Schäfer, W. 1994. Molecular mechanisms of fungal pathogenicity to plants. Annu. Rev. Phytopathol. 32:461-477.

Schröder, M., Hahlbrock, K., and Kombrink, E. 1992. Temporal and spatial patterns of 1,3- $\beta$-glucanase and chitinase induction in potato leaves infected by Phytophthora infestans. Plant J. 2:161-172.

Scott-Graig, S. J., Kerby, K. B., Stein, B. D., and Somerville, S. C. 1995. Expression of an extracellular peroxidase in barley by the powdery mildew pathogen. Physiol. Mol. Plant Pathol. 47:407-418.

Shiraishi, T., Yamada, T., Saitoh, K., Kato, T., Toyoda, K., Yoshioka, H., Kim, H. M., Ichinose, Y., Tahara, M., and Oku, H. 1994. Suppressors: Determinants of specificity produced by plant pathogens. Plant Cell Physiol. 35:1107-1119.

Sierotzki, H., and Gessler, C. 1993. Flavan-3-ol content and the resistance of Malus x domestica to Venturia inaequalis (Cke.) Wint. Physiol. Mol. Plant Pathol. 42:291-297.

Thibault, B., and Le Lézec, M. 1990. Sensibilité au feu bactérien des principales variétés de pommiers et de poiriers utilisées en Europe. Pages 96-106 in: Fire Blight of Pomoideae (Erwinia amylovora, Burrill, Winslow et al.). Applied Research in Europe (1978-1988). EUR 12601 ECSC-EEC-EAEC, Brussels, Luxembourg.

Treutter, D. 2001. Biosynthesis of phenolic compounds and its regulation in apple. Plant Growth Regul. 34:71-89.

Venisse, J. S., Gullner, G., and Brisset, M. N. 2001. Evidence for the involvement of an oxidative stress in the initiation of infection of pear by Erwinia amylovora. Plant Physiol. 125:2164-2172.

Watillon, B., Kettmann, R., Boxus, P., and Burny, A. 1998. Elongation factor $1 \alpha(\mathrm{EF}-1 \alpha)$ transcript levels are developmentally and environmentally regulated in apple plants. Physiol. Plant. 104:1-9.

Wei, Z. M., Laby, R. J., Zumoff, C. H., Bauer, D. W., He, S. Y., Collmer, A., and Beer, S. V. 1992. Harpin, elicitor of the hypersensitive response produced by the plant pathogen Erwinia amylovora. Science 257:85-88.

Wirth, S. J., and Wolf, G. A. 1992. Microplate colorimetric assay for endoacting cellulase, xylanase, chitinase, 1,3- $\beta$-glucanase and amylase extracted from forest soil horizons. Soil Biol. Biochem. 24:511-519. 